\title{
EVERGETISMO Y RELACIONES CLIENTELARES EN LA SOCIEDAD ATENIENSE DEL SIGLO IV A.C.
}

Domingo Plácido, César Fornis

\author{
Presses Universitaires de Franche-Comté | « Dialogues d'histoire ancienne »
}

2011/2 37/2 | pages 19 à 47

ISSN 0755-7256

Article disponible en ligne à l'adresse :

http://www.cairn.info/revue-dialogues-d-histoire-ancienne-2011-2-page-19.htm

\section{Pour citer cet article :}

Domingo Plácido, César Fornis, « Evergetismo y relaciones clientelares en la sociedad ateniense del siglo IV a.C. », Dialogues d'histoire ancienne 2011/2 (37/2), p. 19-47.

DOI 10.3917/dha.372.0019

Distribution électronique Cairn.info pour Presses Universitaires de Franche-Comté.

(C) Presses Universitaires de Franche-Comté. Tous droits réservés pour tous pays.

La reproduction ou représentation de cet article, notamment par photocopie, n'est autorisée que dans les limites des conditions générales d'utilisation du site ou, le cas échéant, des conditions générales de la licence souscrite par votre établissement. Toute autre reproduction ou représentation, en tout ou partie, sous quelque forme et de quelque manière que ce soit, est interdite sauf accord préalable et écrit de l'éditeur, en dehors des cas prévus par la législation en vigueur en France. Il est précisé que son stockage dans une base de données est également interdit. 


\section{Evergetismo y relaciones clientelares en la sociedad ateniense del siglo IV a.C.*}

Domingo Plácido**

César Fornis***

Son magros los estudios sobre la relaciones evergéticas y clientelares en la Grecia clásica. Y los pocos que hay, como el de P. Millett, tienden a considerar que el patronato apenas pudo arraigar en el seno de una sociedad democrática cuyas estructuras y valores no dejaban espacio para su puesta en práctica ${ }^{1}$. Sólo en las figuras del $\kappa o ́ \lambda ~ \alpha \xi$, el adulador, y el $\pi \alpha \rho \alpha ́ \sigma i \tau o \varsigma$, el gorrón, personajes habituales de la comedia nueva, encuentra alguna semejanza con la del cliente, pero sin ser un fenómeno mayoritario y con implicaciones apenas significativas en las relaciones socioeconómicas de la comunidad. En caso de necesidad, un individuo podía contar, según él, con las ayudas del Estado a través de las subvenciones por desempeño de cargo público, lo que no parece suficiente, así como con los préstamos sin interés, éranoi, entre amigos, que bajo nuestro punto de vista ocultan relaciones de patronazgo. Por otro lado, sobre la primera cuestión, es decir, el misthós, es más bien una alternativa al evergetismo, por lo menos a partir de la época de Pericles. Millett concluye entonces que la sociedad de Atenas no se vio alterada o condicionada por este tipo de relaciones verticales.

\footnotetext{
* El presente artículo se enmarca en el proyecto HAR2010-15756, subvencionado por el Ministerio de Ciencia e Innovación.

** Universidad Complutense de Madrid - placido@ghis.ucm.es

*** Universidad de Sevilla - cfornis@us.es

I P. Millett, «Patronage and its Avoidance in Classical Athens», en A. Wallace-Hadrill (ed.), Patronage in Ancient Society, London-New York, 1989, I5-47. M.I. Finley, El nacimiento de la política, Barcelona, I986 (= 1983), 49-68 entendía que la introducción del misthós por el desempeño de funciones públicas convertía al ciudadano en una especie de "cliente del Estado", un patronazgo comunitario que se opondría al patronazgo privado (para una crítica de tal interpretación, véase E. Deniaux, P. Schmitt-Pantel, «La relation patron-client en Grèce et à Rome», Opus 6-8, 1987-89, esp. 152-153).
} 
Otros trabajos que no se ocupan sino tangencialmente del tema, como los de G. Herman y P. Easterling, se limitan a ver en el patronazgo una forma de amistad desigual, sin dejar de señalar las diferencias con las más "codificadas" relaciones entre patrono y cliente de la sociedad romana ${ }^{2}$. Coincidentes en parte son las opiniones de S. Humphryes, J. Ober y C. Mossé, que no obstante introducen matices importantes: la primera prácticamente excluye el patronazgo individual en la Atenas clásica, pero entiende las liturgias como un patronazgo colectivo, no para con la ciudad -como afirman los más ricos en los tribunales-, sino para con grupos más reducidos como el demo, la fratría, el génos, la tribu o los vecinos; el segundo reconoce en la cháris ateniense rasgos de un sistema formal de patronazgo como fue el romano; por fin, la tercera se centra en el patronazgo de dimensión exclusivamente política, en el marco de las heterías y las facciones políticas, cuyos prostátai contaban con personas leales que les prestasen servicios tales como promover decretos en su nombre, proponerles para recompensas honoríficas o testificar a su favor en los tribunales, una relación patronocliente que para Mossé no tiene incidencia en el funcionamiento de la democracia ${ }^{3}$. Por su parte, E. Deniaux y P. Schmitt-Pantel tienden a reconocer un "paréntesis" democrático en la evolución de un patronazgo ateniense mejor atestiguado en las épocas arcaica y helenística ${ }^{4}$, mientras que para J. Gallego, que se centra en el medio rural, el antiguo patronazgo no desapareció, si bien es cierto que, transmutado en evergetismo con el nuevo marco político, perdió peso como modo de dominación del campesinados.

Sobre este fondo, T.W. Gallant parece una rara auis en cuanto a su postulado de que el patronazgo floreció en la sociedad ateniense, particularmente a través de un canal concreto, el de las asociaciones fundadas en vínculos de parentesco ficticios en

2 G. Herman, Ritualised Friendship and the Greek City, Cambridge, 1987, 38-39; P. Easterling, «Friendship and the Greeks», en R. Porter, S. Tomaselli (eds.), The Dialectic of Friendship, London, 1989, I2-I3.

3 S. Humphreys, «Public and Private Interests in Classical Athens», CJ 73, 1977/78, 102; J. Ober, Mass and Elite in Democratic Athens: Rhetoric, Ideology, and the Power of the People, Princeton, 1989, 228-230; C. Mossé, «Peut-on parler de patronage dans 1'Athènes archaïque et classique?», en Religion et anthropologie de l'esclavage et des formes de dépendance, Paris, 1994, 34-36 y «Les relations de 'clientèle' dans le fonctionnement de la démocratie athénienne», Métis 8-9, 1994-95, I43-150.

4 E. Deniaux, P. Schmitt-Pantel, art. cit. (La relation patron-client), I5I, donde se preguntan si en la Atenas clásica no coexistirían dos tipos de "patronazgo comunitario", uno enmarcado por la ciudad (las liturgias) y el otro libre, próximo a las prácticas más propias del arcaísmo y el Helenismo.

5 J. Gallego, «El patronazgo rural en la democracia ateniense», SHHA 27, 2009, 163-175; cf. también, del mismo autor, «Control social, participación popular y patronazgo en la Atenas clásica», Circe de Clásicos y Modernos 12, 2008, 187-206. 
el marco del demo (phratriai, orgéones, thiasoi) ${ }^{6}$; sus argumentos son ardientemente combatidos por I. Arnaoutoglou, para quien «en una sociedad en que la moralidad

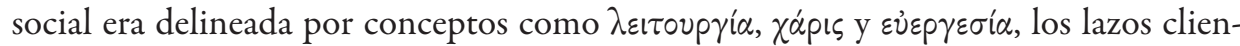
telares eran incompatibles con la idea dominante de ciudadano», de tal manera que solo puede concebir una relación clientelar entre ciudadanos y metecos o extranjeros 7 . Más recientemente R. Zelnick-Abramovitz ha destacado la importancia de la philía entre individuos de desigual condición y/o riqueza como un componente intrínseco de la democracia ateniense, con notables implicaciones tanto en la esfera pública como la privada, a menudo indiferenciables, por lo que puede actuar como eufemismo para relaciones de dependencia ${ }^{8}$; bien distinta entiende la philía $\mathrm{D}$. Konstan, para quien se basaba ante todo en la espontánea generosidad y el sincero afecto por encima de cualquier motivación de buscar beneficio o reciprocidad?.

Desde luego, nadie pretende que en Atenas se dieran formas de clientelas calcadas de las romanas, pero existe un uso de la palabra pelátes que los romanos empleaban para referirse a la clientela y que en Atenas alude a modos de dependencia similares. Dionisio de Halicarnaso, II 9-II, compara las relaciones de dependencia de los thêtes atenienses $\mathrm{y}$ de los penéstai tesalios con las de los clientes romanos ${ }^{10}$. Son aquéllas a cuyo regreso aspiran en el mundo democrático algunos sectores de la clase dominante, que veían en estas dependencias formas menos conflictivas de subordinación. La tendencia a la clientela existe de modo conflictivo, como modo de someter a los libres, que naturalmente se defienden gracias a los instrumentos de la democracia; en el siglo IV esta última se halla en una situación en ocasiones precaria, lo que obliga a admitir que en la realidad de la épocca subyace una tensión social no revelada en graves enfrentamientos, sino en los modos de expresión que, a pesar de estar controlados por los exponentes intelectuales de la oligarquía, no dejan de transparentar las aspiraciones del dêmos. De hecho, en muchos aspectos es el mismo dêmos el que ejerce la capacidad de control de los instrumentos ideológicos, aunque sean oligarcas quienes tienen el poder ${ }^{11}$.

6 T.W. Gallant, Risk and Survival in Ancient Greece. Reconstructing the Rural Domestic Economy, Cambridge, I991, I43-169.

7 I. Arnaoutoglou, «Associations and Patronage in Ancient Athens», AncSoc 25, 1994, 5-17 (la cita es de la p. 16).

8 R. Zelnick-Abramovitz, «Did Patronage Exist in Classical Athens?», $A C$ 79, 2000, 65-80.

9 D. Konstan, Friendship in the Classical World, Cambridge, 1997, esp. 53-92.

Io Texto añadido como Apéndice en la publicación editada por Wallace-Hadrill, op. cit. (Patronage), 243-245.

II J. Ober, The Athenian Revolution. Essays on Ancient Greek Democracy, Princeton, 1996, I54. 
En la Historia de la sociedad griega arcaica, la práctica del evergetismo o beneficencia responde al desarrollo de la ciudad como centro de convivencia y redistribución, dentro de una organización aristocrática, en que se ha subsumido el sistema representado por el ồkos, la casa del jefe como portador del banquete. Junto a las prácticas colectivas de aspecto religioso, los áristoi ejercen formas específicas de redistribución que sirven al mismo tiempo para sustentar la creación de las redes clientelares, lo que repercute en el proceso de formación de los protagonismos individuales cuya culminación está representada por las tiranías.

$\mathrm{Al}$ sur del ágora de Atenas, bajo la thólos, se halla un edificio altamente irregular, conocido como edificio $\mathrm{F}$, que forma parte de una estructura más amplia, con plano complejo, patio de este a oeste, con columnatas a sur y norte y rodeado de habitaciones de tamaños variados; posiblemente se trata del elemento principal de los archeîa o centros de gobierno del siglo VI, anteriores a los prítanes y los buleutas, vinculados a las relaciones clientelares propias de la aristocracia y la tiranía, y un anexo como syssition ${ }^{12}$, que ya se usaba en el tercer cuarto del siglo VI; es posible que haya sido el palacio de los Pisistrátidas ${ }^{13}$. La superposición de la thólos representa simbólicamente la abolición de la tiranía a favor de un sistema isonómico.

En los momentos de tensión que vivió la ciudad de Atenas entre las batallas de Maratón y Salamina, símbolos del cambio del protagonismo militar de los hoplitas a favor de los miembros de la flota, reflejo de más profundas transformaciones en la estructura social, Temístocles pregunta, según Plutarco, Vida de Temistocles, 22, I-2: «¿Por qué os cansáis de ser bien tratados muchas veces de parte de los mismos?», con la expresión êu páschontes. El mismo Plutarco, en Dichos de reyes y emperadores, $\mathrm{I}_{3}$ (= Moralia, ${ }_{185}$ E), utiliza la expresión más plástica euchrestoúmenoi. En Sobre el elogio de uno mismo, 6 (= Moralia, $54 \mathrm{IE}$ ), Plutarco repite la primera versión y añade que Temístocles decía también que cuando hay tempestad se refugian en él, pero, si no, pasan de largo. En las acciones evergéticas, la colectividad aparece como un sujeto puramente pasivo de las acciones de los poderosos y sólo le queda el recurso de la cháris o, alternativamente, la indiferencia ante el poderoso. La beneficencia puede crear rechazo, como señal de prepotencia que conduce a la tiranía; de ahí la importancia del ostracismo, potenciado especialmente en estos momentos, con el que, según el mismo Plutarco, Aristides, 7, 7, condenaron a Aristides por ser «demasiado justo». El debate se plantea sobre el eje del evergetismo, como sistema benéfico, pero también como instrumento de poder de las familias poderosas.

I2 R.E. Wycherley, The Stones of Athens, Princeton, 1978, 28.

I3 J.M. Camp, The Athenian Agora. Excavations in the Heart of Classical Athens, London, 1986, 45. 
La victoria sobre los persas tuvo un primer efecto sobre la ciudad, que exacerbó el patriotismo y la confianza en los personajes más destacados de la vida militar y política, en coincidencia con una nueva valoración de las instituciones tradicionales conservadoras, como el Areópago. En ese ambiente se recrudece la función evergética que aparece representada principalmente por la figura de Cimón, de familia aristocrática, potenciada de modo especial tras las guerras médicas y, sobre todo, por la batalla de Maratón, donde se apareció el héroe Teseo, destacado representante de la tradición heroica ateniense, convertido en símbolo de una democracia patrocinada por la aristocracia. El retrato del personaje en Plutarco, Cimón, Io, I-3, es suficientemente significativo:

Como ya era suficientemente rico, Cimón gastó con gran generosidad en beneficio de los ciudadanos los ingresos procedentes de su expedición, con los que se consideraba que había hecho bien al aprovecharse de los enemigos. En efecto, quitó las vallas de sus campos, a fin de que tanto a los extranjeros como a los ciudadanos que lo necesitaran les fuera posible participar sin problemas de los frutos, y en su casa se hacía cada día una comida frugal, pero suficiente para muchos, a la que acudía cualquier pobre y tenía su alimento sin necesidad de trabajar, con lo que le quedaba el tiempo libre para los asuntos públicos. 2 Sin embargo, según dice Aristóteles, no se preparaba la comida para cualquiera de entre todos los atenienses, sino de entre sus compañeros del demo de los Lacíadas. Iban siempre con él unos jóvenes acompañantes hermosamente vestidos, y uno de ellos, si algún viejo ciudadano mal vestido se encontraba con Cimón, intercambiaba con él los mantos, y que eso fuera así resultaba fuente de prestigio. 3. Ellos mismos, provistos de dinero abundante, se colocaban en el ágora junto a los pobres que se mostraran tímidos y les daban en las manos monedas silenciosamente ${ }^{14}$.

En los tiempos posteriores, a partir de la reformas de Efialtes y del protagonismo de Pericles en la vida política ateniense, las circunstancias cambian y se imponen otros sistemas de redistribución más acordes con el régimen democrático. Sin embargo, sobre todo en momentos de crisis, surgen voces que expresan su añoranza del evergetismo como modo más eficaz del mantenimiento del sistema de consenso, para que los ricos protejan a los pobres y éstos admiren y respeten a aquéllos. Un ejemplo claro está representado por Isócrates, en su elogio de la institución del Areópago como modelo del sistema tradicional, institución que precisamente inicia su decadencia a partir de las reformas de Efialtes ${ }^{15}$.

I4 Trad. de Domingo Plácido (Madrid, Alianza, 1999).

is D. Plácido, «¿Hubo previsión social en las sociedades preindustriales? Estado de la cuestión y vías de investigación. La Antigüedad», en S. Castillo, R. Ruzafa (coords.), La previsión social en la Historia. Actas del VI Congreso de Historia Social de España, Vitoria, 3-5 de julio de 2008, Madrid, 2009, II-I6. 
En esta última época, los datos literarios contemporáneos, tanto de la oratoria como de la comedia, principalmente, informan con más detalle de las mencionadas prácticas y permiten comprobar que el evergetismo y el clientelismo tuvieron bastante más presencia e incidencia de lo que tiende a reconocerse, ocupando un lugar nada desdeñable en el funcionamiento de la democracia ateniense del siglo IV a.C., una democracia más conservadora que la del siglo precedente, en la que se consiguen frenar y controlar los "excesos" (reales o potenciales) del poder del dêmos, lo que algunos han interpretado como "dominio de la ley" ${ }^{16}$, pero que sin duda implicaba la recuperación por los dominantes de sus posibilidades de explotación al apropiarse del excedente de los trabajadores, a través de formas no coactivas de poder, sin necesidad de coerción extraeconómica ${ }^{17}$. Entendemos, por tanto, que el evergetismo y el clientelismo son mecanismos fundamentales en la "vigilancia" interna establecida por los oligarcas atenienses sobre la politeía democrática de su comunidad.

El discurso más antiguo de los preservados de Isócrates es el Contra Eutínoo (XXI), de los años inmediatamente posteriores a los Treinta, en el que se apoya a un Nicias que tuvo miedo en el período de la oligarquía. Nicias es un rico cuya posición en contra de Eutínoo la asume alguien por ser su amigo (I), que es quien encarga el discurso a Isócrates. El acusado, pariente suyo, sólo le devolvió dos talentos de los tres que Nicias le había depositado en el momento de huir de los Treinta, que ya le habían privado de sus derechos de ciudadanía (2). Nicias es más rico que Eutínoo (5), pero el otro tiene muchos amigos, lo que le convierte en poco apto para demandarle (9). Eutínoo se aprovecha del miedo de los ricos como Nicias en dicho momento (I2) y este último se sentía amenazado (I4). El orador conoce más casos del mismo comportamiento (I7).

El cliente de Isócrates en XVIII, Recurso contra Calímaco, era epitédeios de Patrocles, el arconte rey que había condenado a Calímaco (5). Éste culpaba al acusador de la responsabilidad de la condena de confiscación en la época de los Diez que sucedieron a los Treinta (7). Calímaco le enviaba a sus asiduos (chrómenoi) para tratar de persuadirlo de que abandonara (9).

En XVII, Sobre un asunto bancario, 2, pronunciado en 393, el denunciante expresa las dificultades a que se enfrenta quien se opone a alguien con muchos amigos y muchos recursos (2) -nada menos que Pasión, el famoso banquero ateniense-, pues los acuerdos se establecían sin testigos, en relaciones apoyadas en la philía. El demandante era familia del demandado: oikeios (6). De hecho, dice que el demandado le había ofrecido un acuerdo para la devolución del dinero (29-3I). En 33 se nos habla de las

I6 M. Ostwald, From Popular Sovereignty to the Sovereignty of Law, Berkeley-Los Angeles, 1986.

17 Ober, op. cit. (Athenian Revolution), 88-89. 
ilegalidades cometidas por sus amigos, como abrir las urnas selladas con los jurados de las Dionisíacas, a lo que no se atreve ninguno de los «pequeños» (mikrôn); pero ellos se atreven a base de dinero para ganarse a los esclavos (paîdas) (34). Los contrincantes pueden decir que Pasión con su dinero avaló un préstamo al huésped y amigo (xénon... kai epitédeion) del demandante (38). El orador, aunque es extranjero y vive en el Ponto, dice tener fortuna suficiente para hacer bien a otros atenienses (56); invoca además la posición de su padre ante Sátiro, rey del Ponto, que ha beneficiado a los atenienses por encima de otros griegos con el envío de grano en períodos de escasez y que en los contratos privados les ha concedido cláusulas ventajosas (57).

El discurso de Isócrates, XX, Contra Loquites, fue pronunciado en los primeros años del siglo IV, entre 400 y 396 . El protagonista es un individuo que ha sido golpeado por un rico. Según el orador, son más graves los daños corporales que los que afectan a la riqueza, «porque combatimos por la libertad y luchamos por la democracia» (I). Se revela aquí la necesidad de los pobres de defenderse de los abusos de los ricos al final de la guerra del Peloponeso. El derecho se define como protección de la persona y no de la propiedad. Es más grave cometer violencia en la democracia que durante la oligarquía, como es el caso de Loquites (4): «Debéis cuidaros más de aquéllos, que habrían sido peores aún en la oligarquía, cuando la violencia estaba permitida $\gg$. Es una muestra de que continúan los abusos de los ricos en la restauración. Está más afectado por la deshonra que por los golpes (5). Es el mayor motivo de irritación para los libres (6), donde se incluyen los jurados, libres en peligro de caer bajo los abusos de los poderosos. Se trata de una defensa de la libertad de los pobres. Hay que tener en cuenta que se trata de hýbris (7), que la democracia debe castigar. En la época de la democracia en peligro, la hýbris se orienta sobre todo hacia la violencia social, que no se ha borrado con el final de la oligarquía. Los violentos causan las mayores desgracias (8). «El asunto os afecta como conjunto, porque ha dañado casas y ciudades» (9): sin duda se trata de la violencia contra el pueblo por parte de los poderosos, capaces de abusar de aquellos que, por su condición de inferioridad económica, entran en una situación de peligro para su propia libertad. Por ello alude a las dos veces que se ha destruido la democracia y la libertad por parte de quienes desean ser esclavos de los enemigos, los filolaconios, y tratan de injuriar (íßpí(zlv) a los ciudadanos (Io). El pueblo se tiene que defender con los instrumentos democráticos frente a la hýbris de los poderosos incluso tras la restauración, aunque tal hýbris se sustente en una superioridad paralela a su propia inferioridad. Aunque Loquites es más joven, tiene el carácter (trópos) propio de aquella politeía (II). No sólo hay que castigarlos a aquéllos, sino a los que ahora quieren colocar a la ciudad en la misma situación (I2): considera que son comportamientos que llevan a 
la oligarquía, aunque estén dentro del sistema democrático. «No esperéis a que tengan otra ocasión. Castigadlos en cuanto se detecte su maldad como enemigos comunes» (13-14). El sistema oligárquico se contempla como la culminación de un proceso de desequilibrio social que facilita el desarrollo de la hýbris. Los pobres no comparten los riesgos de los ricos en cuanto a la fortuna, pero los riesgos corporales afectan a todos, por lo que «cuando castigáis a los ladrones protegéis a los ricos, pero cuando castigáis a

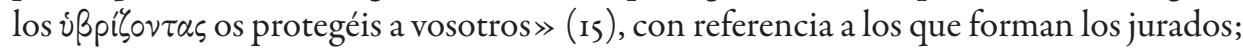
es muy importante el proceso sobre la hýbris (I6), que viene a ser la defensa de la democracia; «al castigarlo haréis a los ciudadanos más ordenados y la vida más segura; no es justo que lo castiguéis menos porque yo sea pobre» (I8-19); en la ciudad democrática los pobres también tienen derecho a la protección, no sólo a desempeñar magistraturas e ir a la guerra (20), lo que quiere decir que la democracia tiene que ser social, y no sólo política; es la causa de los ciudadanos (2I); «por eso debéis castigar a Loquites» (22). En estos momentos, se trata sin duda de un derecho que tiene necesidad de ser reivindicado.

Tras la caída de los Treinta, los oligarcas continúan su actitud prepotente con el dêmos, de modo que ésta se convierte en el modelo de hýbris. Frente a ello, Isócrates comparte en principio las mismas contradicciones que Terámenes ${ }^{18}$, según se deduce de las Vidas de los diez oradores, IV 3 (= Moralia, 836F-837A), atribuidas a Plutarco, que lo define como enemigo de la oligarquía. Incluso puede admitirse la influencia de Terámenes en la teoría de la pátrios politeía tal como aparece en Isócrates ${ }^{19}$. Ahora bien, Isócrates también interviene en XVIII, Recurso contra Calímaco, en apoyo del cumplimiento de la ley de amnistía de Arquino en favor de los oligarcas, seguramente en $40 \mathrm{O}$. El orador elogia la situación de Atenas como consecuencia de la reconciliación (46). El cliente de Nicias usa como argumento sus servicios al Estado, sobre todo el aprovisionamiento de los del Pireo cuando Lisandro lo había prohibido (6I), por lo que había recibido una corona, y cree que puede considerarse entre los "demóticos" (62) ${ }^{20}$.

Una acusación parecida es la que lleva a cabo el Contra Conón, incluido en el corpus Demosthenicum, LIV, en el que el autor califica de insolente al demandado de uno de los hijos de kaloi kagathoi (I4). Estos jóvenes se apoyan mutuamente en los testimonios, como hetaîroi kai philoi (35).

I8 D. Plácido, «La recuperación del pasado en la Atenas del siglo IV», en F. Gascó, E. Falque (eds.), El pasado renacido, Sevilla, I992, II-23, esp. I5.

19 M.L.W. Laistner, Isocrates De Pace and Philippus, New York-London, 1927, I2.

20 C. Fornis, D. Plácido, «De la guerra del Peloponeso a la paz del Rey (III): los factores económico públicos y privados en Atenas», Gerión, 27, I, 2009, 155-156. 
En el Eginético (XIX), de 391 o 390, el orador recuerda en nombre de su cliente sus acciones hacia el muerto cuya herencia se disputa, mientras que la oponente nunca habría sido buena (chrestèn) con él (2-3). El padre del muerto, Trasilo, no había heredado nada de sus progenitores, sino de Poleméneto, de quien era xénos, con quien estableció relaciones familiares, oikeios (5). Basa sus derechos en la philía (Io). Le interesa marcar la diferencia entre el parentesco (katà génos) y la amistad (17). Trasíloco ha querido dejar su hacienda a sus amigos (32), que se ocuparon de él durante su enfermedad. Mostraba así su philois chárin (34). La reclamación se basa en las largas relaciones de philía y en las evergesias prestadas al difunto (50).

Isócrates escribe el Areopagitico (VII) hacia 355; en 52 representa la nostalgia de los campesinos por la época anterior a la guerra del Peloponeso, con predominio del Areópago y de la vida del campo. Proclama por ello la vuelta al sistema patrio (I5-16), con la abolición del sorteo y del misthós (2I-27), para que sean los que tienen scholé los que se ocupen de los asuntos públicos ${ }^{21}$. En ese contexto entona la alabanza del patronato (32-35). Enuncia la teoría de que la eudaimonía de unos dependía de la euporía de los otros. Se refiere a una época idílica localizada en el pasado, cuando existía la concordia basada en relaciones de evergetismo. Los ricos pensaban que los pobres eran una vergüenza para ellos y se inclinaban a solucionar sus problemas a través de la redistribución individual. Nadie ocultaba su hacienda, sino que la usaba en beneficio de la colectividad. La añoranza del evergetismo se contrapone a las obligaciones litúrgicas,

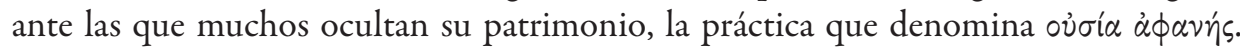
El orador alaba asimismo la práctica de la cesión de tierras por un misthós moderado; los ricos hacían así trabajar y sacaban provecho $(34)^{22}$. Se trata de sustituir el misthós político como pago por funciones públicas por el misthós como renta de trabajo, como el practicado en las explotaciones agrarias del arcaísmo, según Isócrates. Es una faceta de la teoría de que la riqueza de los ricos es beneficiosa para todos. El planteamiento de Isócrates busca una solución interclasista, en la que los pobres, más que reclamar protagonismo, adoptan una actitud agradecida y complaciente, en concordancia con la actitud de los ricos, que deben ejercer el evergetismo de modo voluntario. Por ello, los pobres serán más felices cuanta más capacidad tengan los ricos para llevar a cabo la redistribución de sus riquezas por los métodos propios de la ciudad democrática.

2I Así también Mossé, art. cit. (Peut-on parler), 33, que niega el carácter utópico que en ocasiones se otorga a un pasaje que en realidad plantea «revenir à ces pratiques de générosité privée qui assuraient aux riches le contrôle de la vie de la cité».

22 E.M. Wood, «La polis y el ciudadano-campesino», en J. Gallego (ed.), El mundo rural en la Grecia antigua, Madrid, 2003, 290. 
Por ello mismo, Aristóteles, Ética nicomáquea, VIII 8, Io (=II59bi2); I4, I (= II63bi), habla de las posibilidades de amistad entre ricos y pobres, en que éstos ofrecen honor al benefactor ${ }^{23}$. Tal es la práctica que recibe el nombre de philanthropía. Isócrates se define así como neocimoniano, que defiende la sociedad regida por las relaciones de patronato y una recuperación del papel predominante del Areópago ${ }^{24}$. En correspondencia, emprende el ataque a los excesos de democracia, la akolasía y la parrhesía (20). En la línea de Cimón, Andócides I, Sobre los misterios, I47, afirma que la casa familiar había estado siempre abierta a quienes lo necesitaban. Así se identifica con la tradición representada por Cimón en los momentos previos a la consolidación de la democracia como sistema público de distribución ${ }^{25}$.

Entre los consejos de Isócrates a Nicocles (II) i5, destaca el de velar por la masa y mandar kecharisménos, de modo que se imponga la cháris; Lisias, VIII, Discurso de acusación contra los socios por injurias, sin embargo, se pronuncia contra los compañeros de asociación, synousiastás, y contra los aparentes amigos (2). Las asociaciones de culto sirven como instrumento del evergetismo ${ }^{26}$. Se pone de relieve la celebración común de algunas ceremonias como la procesión (xyntheoreîn) a Eleusis (5). También señala el contraste entre tener muchos o pocos amigos en relación con la pobreza (7). El demandante había confiado en la protección de los amigos (17) y se aparta de la philía porque ha constatado que no ganaba nada (I8).

En los consejos a Demonico (I), Isócrates le explica que la mejor manera de ser útil a los amigos es acudir de modo espontáneo a sus necesidades, sin esperar a que lo manifiesten (25). Es vergonzoso ser vencido por los amigos en evergesias. Una de las ventajas de poseer una hacienda es poder ayudar al amigo necesitado (28). Los malos dañan a sus benefactores (29). Cuando se acercan hay que ser amable (bomiletikós), pero

23 A.R. Hands, Charities and Social Aid in Greece and Rome, London, 1968, 32-33.

24 Efectivamente desde mediados del siglo IV el aristocrático Consejo del Areópago recupera relevancia política y social en el marco de formas de gobierno más centralizadas y autoritarias mostradas por la democracia ateniense; véase al respecto M. Valdés, D. Plácido, C. Fornis, «El sacrificio a las Semnai Theai en Atenas: autoridad y silencio (hesychia) en el Areópago y revitalización del culto en el siglo IV», en S. Montero, $\mathrm{M}^{\mathrm{a}}$.C. Cardete (eds.), Religión y silencio: El silencio en las religiones antiguas, Ilu. Revista de Ciencias de las Religiones, Anejo XIX, Madrid, 2007, I07-132, donde se encontrará la bibliografía anterior.

25 M.M. Markle, «Jury Pay and Assembly Pay at Athens», en P.A. Cartledge, F.D. Harvey (eds.), Crux. Essays in Greek History presented to G.E.M. de Ste. Croix, London, 1985, 286.

26 Gallant, op. cit. (Risk and Survival), I43-169; también se desprende implícitamente de I. Arnaoutoglou, «Between koinon and idion: legal and social dimensions of religious associations in ancient Athens», en P. Cartledge, P. Millet \& S. von Reden (eds.), Kosmos. Essays in order, conflict and community in classical Athens, Cambridge, 1998, 8I, incluso si este autor no parece inclinado a reconocer los vínculos clientelares propiamente dichos (cf. supra con n. 7). 
no solemne, pues es insoportable sentirse humillado incluso para los esclavos (30). La referencia es especialmente interesante porque pone de manifiesto que el evergetismo crea relaciones de dependencia por medio de la violencia simbólica.

En la Antídosis (XV), del año 353, Isócrates reclama ( 158 ) que se tengan en cuenta sus actos de evergetismo en relación con las acusaciones que se le hacen de evitar las liturgias ${ }^{27}$. Como en otros casos, los poderosos reclaman que se reconozca la compensación de las liturgias por actos de evergetismo.

En el último discurso de Isócrates, el Panatenaico, el orador alaba el comportamiento imperialista de Atenas porque así (47) promovió la prosperidad de Grecia, la superioridad de Europa sobre Asia, satisfizo las exigencias de los griegos pobres y promovió la humillación de los bárbaros ${ }^{28}$. Atenas se presenta así como evérgeta a escala panhelénica, promotora de beneficios que justifican su superioridad, su capacidad para obtener la cháris de los griegos, en la misma proyección que utilizaba Pericles en el discurso que reproduce Tucídides (II 40,4) ${ }^{29}$, donde se entendían como clientelares las relaciones imperialistas. Las relaciones de basan en la eúnoia y la philía.

Menandro, en El misántropo (Dýscolos), 366-367, habla, por boca de Daos, esclavo de Gorgias, hijo del misántropo Cnemón, de que si Sóstrato quiere obtener en matrimonio a la hija de éste, tiene que ofrecer su cooperación en el trabajo, para que lo considere un pobre trabajador del campo, autourgón... péneth'. Sóstrato declara que considera amigo a Quéreas (56), que es un parásito y, en un momento determinado (I30-13I), dice que es una cosa muy amarga un campesino pobre. En 293-298, Gorgias advierte a Sóstrato del peligro de que su scholé se convierta en hýbris. Gorgias dice de su padre que se trata de alguien que está solo en el trabajo (329-33I), sin synergón... oikéten... misthotón ${ }^{30}$. Dice que Cnemón, el misántropo, padre de la pretendida, no soportará verte «en el ocio y el lujo» (ágonta scholèn tryphôntá t’) (357). Gorgias se niega a aceptar nada de Sóstrato, porque «tenemos de todo» (6I2). Sóstrato justifica su insistencia en que «soy tu amigo desde hace tiempo, antes de haberte visto» (6I5-616). En la escena final Sóstrato (797-8I2) trata de convencer a su padre para que "invierta" en vincularse a Cnemón casando a su hija con el hijastro de éste, porque «un amigo evidente (emphanès

27 Y.L. Too, A Commentary on Isocrates' Antidosis, Oxford, 2008, 7.

28 A. Masaracchia, Isocrate. Retorica e politica, Roma, 1995, 91.

29 D. Plácido, La sociedad ateniense. La evolución social de Atenas durante la guerra del Peloponeso, Barcelona, 1997, 39.

30 R. Osborne, Demos: The Discovery of Classical Attika, Cambridge, 1985, 145. 
phílos) es mucho mejor que una riqueza oculta (ploûtos aphanés) ${ }^{31}$; la philía, entonces, es buscada por el interés que puede rendir en cualquier momento y por la seguridad que puede dar si llegan malos tiempos, levantada como está sobre las obligaciones morales inherentes a la $\chi \alpha \dot{\alpha}$ is y el $\alpha i \delta \omega^{\prime} \varsigma^{32}$. Sin duda se trata de un caso específico, de un personaje peculiar, dentro del género cómico, pero su eficacia como tal se basa en ciertas relaciones con la realidad, que aquí se encuentran en las necesidades de los campesinos pobres de ponerse al servicio de los más ricos. El autourgós deja de ser propiamente tal al tener que trabajar por cuenta ajena. En general, Menandro refleja la concentración de las preocupaciones de la población en las relaciones privadas en una época que coincide con la pérdida de derechos que tiene lugar desde el año 322 (Diodoro, XVIII I8, 5; Plutarco, Vida de Foción, 28), acentuada con Demetrio de Falero en 317, con apoyo de Casandro ${ }^{33}$. La situación da pie a que los que carecen de medios se conviertan en dependientes de los poderosos, de ahí que Gorgias rechace «recibir mucho, mientras él posee poco» $(834)$.

Cnemón se caracteriza por su avaricia, lo mismo que Esmicrines, de Aspis, el Escudo, al que Fortuna define porque «no tiene pariente ni amigo» (I2I-I22), que son normalmente los objetos del evergetismo. Su hermano y contrapunto, Queréstrato, se caracteriza en cambio por ser «bueno y rico» (I29-130) y por comportarse generosamente con parientes y amigos. En 310, Daos espera que éste no abandone a sus amigos, toùs philous, ante las arbitrariedades de Esmicrines.

El evergetismo, en la concepción expuesta por Demóstenes en el discurso XX, Contra Leptines, se convierte en la proyección pública de las relaciones clientelares. Demóstenes considera que (IO), si no se mantienen los privilegios de los evérgetas, se os considerará «envidiosos, desleales, ingratos», los conceptos opuestos a los que califican a los «buenos dependientes», sobre todo el último, formado sobre cháris, que viene a ser el término utilizado para señalar las obligaciones de quienes deben gratitud por los favores recibidos. Esto se inserta en la tradición de la escuela socrática. En efecto, en Memorables (II 2, I-2), Sócrates enseña a su hijo Lamprocles la injusticia en que incurre un desagradecido; asimismo Aristóteles (Ética nicomáquea, I167b17-18) asegura

3I Como apunta S. von Reden, «Reciprocity and its Perversions in Menander», C. Gill, N. Postlethwaite, R. Seaford (eds.), Reciprocity in Ancient Greece, Oxford, 1998, 265-266, Sóstrato estaría recomendando usar a los amigos más que el dinero para producir interés, lo que efectivamente se materializaría para su padre tras el intercambio de dotes.

32 Zelnick-Abramovitz, art. cit. (Did Patronage Exist), 67-68.

33 A.W. Gomme, F.-H. Sandbach, Menander. A Commentary, Oxford, 1973, 22, 26. 
que «los bienhechores quieren más a aquellos a quienes han favorecido, que éstos a aquéllos»; en un fragmento de Menandro encontramos que algunos llegan a odiar a quienes han tenido una buena acción con ellos $^{34}$. La cháris se ha considerado un medio de reforzar el poder por parte de la clase dominante, pero el poder político y no sólo el socioeconómico ${ }^{35}$, lo que se encuentra claramente expresado en Lisias XXV, Discurso de defensa por intentos de derrocar la democracia, I2-13, donde el hablante reconoce con candorosa -o brutal, según se mire- sinceridad que su liberalidad pública no es sino una "inversión" destinada a ganar la consideración de sus conciudadanos y tener más posibilidades de defensa en futuros litigios; además, asegura que cumplir con numerosas liturgias y con mayor esplendidez de la que se le requería le había privado del favor de los oligarcas cuando la democracia fue arrumbada. En el mismo sentido XX, En favor de Polistrato, $3 \mathrm{I}$ : «Y es que no os hacíamos bien por dinero, sino para recibir de vosotros un agradecimiento condigno, siendo reclamada nuestra absolución en el caso de que algún día tuviéramos un proceso»; Pap. Ryl. 3.489 col. 3 1l. 60-76 (En defensa de Eriximaco): «He corrido riesgos y gastado con prodigalidad en vuestro nombre para que el estado pudiera ser próspero y, si alguna vez iba al juzgado con una falsa acusación, poder sentirme más confiado» ${ }^{36}$. De la misma manera, en Teofrasto, Caracteres, XXIX 4a, vemos al individuo que se muestra favorable a los encausados en la Asamblea o los tribunales, le ayuda instigando a sus compañeros de asiento contra los acusadores, sicofantas, y argumentando que, si se condena a sujetos de esta especie, nadie querrá exponerse a la animadversión en defensa del bien común.

Así pues, Demóstenes y la comedia nueva advierten de la necesidad de que quien recibe un favor mantenga vivo el recuerdo, mientras que quien lo hace debe olvidarlo ${ }^{37}$. Desde luego estas declaraciones parecen dar respuesta al planteamiento de Hands de que bordeamos la cuestión filosófica de si un hombre es capaz de un acto completamente altruista en todos los sentidos ${ }^{38}$. De ahí que se extienda la polémica sobre la práctica del evergetismo y los deberes de los ricos con la ciudad y la importancia de las liturgias como modo de aportación más controlable. En Atenas las liturgias funcionaban como modo de redistribución, para aminorar las desigualdades, consideradas

34 J.M. Edmonds, The Fragments of Attic Comedy, Leiden, 1961, IIIB 917.

35 J.K. Davies, Wealth and the Power of Wealth in Classical Athens, Salem, 1984, 92-94.

36 Citado por Davies, op. cit. (Wealth), 93 n. 9 y P. Millett, «The Rhetoric of Reciprocity in Classical Athens», en Gill, Postlethwaite, Seaford, op. cit. (Reciprocity), 232 n. 9.

37 Dem. XVIII, Sobre la corona, 269; J.M. Edmonds, The Fragments of Attic Comedy, Leiden, I957, III 749 .

38 Hands, op. cit. (Charities), 44. 
como derecho de los ciudadanos pobres ${ }^{39}$. Conón ha construido un templo de Afrodita en el Pireo. Los atenienses han erigido una estatua de Conón en el ágora. Demóstenes, XX, Contra Leptines, utiliza el ejemplo para señalar las ventajas de la práctica del evergetismo para la ciudad en un discurso sobre la inmunidad, frente a Leptines, que había propuesto que se eliminaran las exenciones en el desempeño de las liturgias, hacia la década posterior a los Treinta. La cuestión era que se eximía a los evérgetas. El "argumento" dice que la propuesta de Leptines se basaba en que, si se eximía a los ricos, se corría el riesgo de que las liturgias recayeran sobre los pobres, que los ricos se enriquecieran sin temor y los pobres tuvieran que prestar liturgias. Pero el acusador dice que el pueblo quedará sin benefactores, como Leucón, que dejará de enviar trigo del Bósforo. La importación del grano era fundamental para el aprovisionamiento de la ciudad de Atenas, con una producción de cereales tradicionalmente escasa en relación a la población ${ }^{4}$. La maniobra de Demóstenes ha consistido en incluir a los evérgetas externos, que en efecto resultan necesarios para el abastecimiento ateniense, siempre en precario, cuando de lo que al parecer ha tratado Leptines es de eliminar privilegios a los ricos atenienses. Leptines en cambio invoca la escasez de quienes pueden ejercer liturgias entre los ciudadanos. Es injusto que los ricos lo sean precisamente por dejar de prestar liturgias. Para Demóstenes sería quitar al pueblo el privilegio de dar (2); pensar que es fácil engañar al pueblo sería quitarle sus derechos de decidir (3). Sin embargo, Demóstenes parte (5) de una argumentación que parece invertir las relaciones clientelares al presentar al pueblo como kyrious, como señores que reciben dones, doreiai, por el hecho de honrar los méritos, porque si el pueblo concede más honores «muchos se ven obligados a atenderos». Aunque inmediatamente (6) queda claro que lo peor es no honrar al que hace los beneficios. Éste debe recibir la timé del pueblo. Los dones que reciben los "buenos" (chrésimoi) son equivalentes a los honores (7). Para Demóstenes (I0), la tradición de la ciudad entre los antepasados era de generosidad, de preocuparse más por el honor que por el dinero, con lo que alude a la época de Pericles, que se refería a la ciudad que daba y recibía agradecimiento, situación comparable, pero si se cambian los términos, porque ahora el agradecido es el pueblo ante sus ricos. Propone hacer lo justo a los evérgetas (I2). Demóstenes diferencia los dones del pueblo de los que conceden los tiranos y las oligarquías ( I5), que hacen ricos a quienes quieren, mientras que el pueblo busca el honor y la firmeza. De este modo se define el sistema democrático de acuerdo con las tradiciones que hacen al pueblo el señor que concede los dones como modo de alcanzar la estabilidad. Recibir del pueblo no produce la vergüenza del adulador (I6),

39 Ober, op. cit. (Mass and Elite), 107.

40 G.I. Oliver, War, Food, and Politics in Early Hellenistic Athens, Oxford, 2007, 20. 
sino el honor merecido y la admiración de los iguales; mientras que recibir del déspota produce temor al futuro. Si se elimina la confianza en los dones (17), se elimina la posibilidad de mostrar cháris a los partidarios de la politeía. Se acentúa la correspondencia entre los dones del pueblo y los dones de los evérgetas, para compaginar la tradición democrática del pueblo soberano (kýrios) con la tradición aristocrática. Las cargas de las liturgias no caerán sobre los pobres, porque la inmunidad no se aplica a las contribuciones de la guerra o de la salvación de la ciudad, ni a la eisphorá ni a la trierarquía (I8), sino a la de los ciudadanos y metecos. La atéleia por evergetismo no afecta a las grandes contribuciones y, en cambio, favorece la participación de los evérgetas. Ésta favorece la confianza (24-25). La riqueza favorece al pueblo (26). Leucón del Bósforo es más beneficioso con sus regalos que con las liturgias, con la administración de Calístenes (33). Él siempre muestra su buena voluntad hacia vosotros (prothymoúmenos) (37). Porque haya indeseables, no se puede privar a los dignos de cháris (39). Todos los que hacen bien tienen derecho a cháris (46). El orador pone como ejemplos de benefactores extranjeros a quienes han facilitado la entrega de Tasos o Bizancio a Trasibulo, lo que parece sugerir la existencia de relaciones clientelares externas en los procesos imperialistas (59-60). En general, en este discurso, Demóstenes equipara los honores prestados a los benefactores públicos, a través de acciones políticas, o a los caídos en la guerra, con los privilegios concedidos a los evérgetas particulares. A pesar de que de alguna fuente tardía se deduce que el discurso habría resultado victorioso, los datos epigráficos parecen indicar que no volvió a haber inmunidad y que algún evérgeta conocido desempeñó funciones litúrgicas ${ }^{41}$.

El discurso XX, Contra Leptines, de la primera etapa de la carrera de Demóstenes (355/4), encaja con su relación con Eubulo, partidario de conservar las exenciones fiscales para los ricos, frente a la posición de los demócratas más radicales conducidos por Aristofonte ${ }^{42}$. Lo compone para Ctesipo, hijo de Cabrias, muerto dos años antes en la batalla de Quíos, de quien hace un elogio (75-83). Habla igualmente bien de Conón, de Ifícrates y de Timoteo, como benefactores de la ciudad. En la misma línea parecen estar Androción y Timócrates, objetivos de los discursos XXII, Contra Androción, y

4I O. Navarre, O. Orsini, « Notice » a Démosthène. Plaidoyers Politiques. I, Paris, Les Belles Lettres, $1968^{2}, 55$.

42 Así también C. Bearzot, «L'orazione demostenica Contro Leptine e la polemica sulla morte di Cabria», en M. Sordi (a. c.), Dulce et decorum pro patria mori: la morte in combattimento nell'antichitá, CISA 16, Milano, 1990, 95-96. Tanto ella como E. Bianco, Lo stratego Timoteo, torre di Atene, Alessandria, 2007, 94 enmarcan el discurso en el debate creado por la muerte de Cabrias: temerario en su estrategia y responsable de la derrota en Quíos para los atenienses más radicales, héroe que se ha sacrificado por la gloria de la ciudad para los más moderados. 
XXIV, Contra Timócrates, de Demóstenes. Ifícrates parece de condición humilde -hijo de un zapatero, se preciaba de que su linaje comenzaba con él ${ }^{43}$-, protegido por la familia de Conón. El nombramiento a una edad muy temprana de Ifícrates como comandante de los peltastas mercenarios que operaban en el área del istmo de Corinto

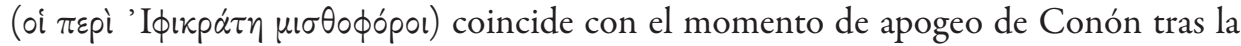
victoria en Cnido y con la ayuda financiera persa a Atenas, aunque no hay prueba fehaciente de que el primero fuera miembro del círculo de amigos del segundo ni de subsecuente colaboración política o militar entre ambos ${ }^{44}$. Según Sealey, en el mismo grupo se incluye Agirrio ${ }^{45}$. Ifícrates se enriquece con su carrera militar y con su servicio como mercenario en Egipto, como hiciera Conón para el Gran Rey, de modo que su hijo Menesteo es capaz de cumplir con liturgias, incluso antes de la edad legal, quizá para contrarrestar las dudas que se cernían sobre la legitimidad de su derecho de ciudadanía, dado que su madre era tracia ${ }^{46}$. De la misma manera Foción se puso al principio de su carrera pública bajo la protección de Cabrias (Plutarco, Vida de Foción, 6, I), en forma de philía productiva sobre todo para el primero; a la muerte de Cabrias, Foción afirmó pagar esa philía con gran cháris cuidando de sus parientes, en especial de su problemático hijo Ctesipo $(7,2)$.

En Demóstenes, LIII, Contra Nicóstrato, el autor trata de los beneficios prestados por Apolodoro a Nicóstrato, como se comportan los vecinos en el campo. Nicóstrato obtenía de Apolodoro lo que necesitaba y a cambio no le era inútil en el cuidado y administración (epimelethênai kai diokêsai) mientras él se dedicaba a sus asuntos públicos y privados, como la trierarquía (4); Nicóstrato fue vendido como esclavo mientras hacía un servicio a Apolodoro, y su familia no tiene medios de rescate (6), por lo que le piden ayuda a éste, que ya había dado un dinero (7); Apolodoro se declara amigo verdadero y le ofrece el éranos (8). Le ha dado mil dracmas (9) como regalo (doreán). Por otra parte, los acreedores, presentados como xénoi, le reclamaban el pago de los préstamos y su

43 Lys. fr. 7.5; Arist. Rh. 1367bi8; Plu. Mor. 186F, 187B. Para el stémma genealógico de Ifícrates, véase la Tabla VI de J.K. Davies, Athenian Propertied Families 600-300 B.C., Oxford, 197 I.

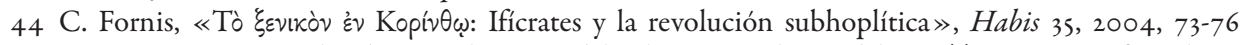
con n. Io; C. Fornis, D. Plácido, «De la guerra del Peloponeso a la paz del Rey (I): prosopografía política ateniense», $R S A$ 38, 2008, 40-42, sobre la dificultad de encuadrar esquemáticamente las posiciones políticas de la época.

45 R. Sealey, «Callistratos of Afidna and his Contemporaries», Historia, 5, 1956, I84, pero véase n. anterior.

46 Arist. Rhet. 1399a35. Cf. Davies, op. cit. (Athenian Propertied), 250; J.T. Roberts, «Aristocratic Democracy: The Perseverance of Timocratic Principles in Athenian Government», Athenaeum 64, 1986, 366. 
hermano los esclavos que había puesto como prenda (Io). Nicóstrato corre el riesgo de ser agógimos, sometido a esclavitud por deudas (II). Necesita reunir el éranos para no caer en manos del que lo libere. Apolodoro reacciona como amigo, phílos (I2); le ofrece el éranos. Nicóstrato lo deja actuar y el otro se hipoteca, pero Nicóstrato no se lo agradece: no le da ninguna chárin y lo deja como un inexperto y como deudor (I3 ${ }^{47}$. Estas relaciones entre amistad y cháris en los vínculos clientelares aparecen igualmente en Jenofonte, Memorables, II 4, I, como forma de inversión rentable; «Porque el buen amigo está siempre en su sitio dispuesto a proveer a su amigo en todo lo que le falte, ya sea para la gestión de sus asuntos privados o de las actividades públicas [...], unas veces contribuyendo a los gastos, otras trabajando con él, otras ayudando a persuadir u obligando a la fuerza $\left(\mathrm{II}_{4}, 6\right)^{48}$. Así también en Platón, Fedro, $233 \mathrm{~d}-\mathrm{e}$ : «Si, además, es menester conceder favores a quienes más nos los reclaman, conviene mostrar benevolencia, no a los satisfechos, sino a los descarriados. Precisamente aquellos que se han liberado, así, de mayores males serán los más agradecidos. Incluso para nuestros convites, no habría que llamar a los amigos, sino a los pordioseros y a los que necesitan hartarse. Porque son ellos los que manifestarán su afecto, los que darán compañía, los que vendrán a la puerta y mostrarán su gozo y nos quedarán agradecidos, pidiendo, además, que se acrecienten nuestros bienes. Pero, igualmente, conviene mostrar nuestra benevolencia, no a los más necesitados, sino a los que mejor pueden devolver favores ${ }^{49}$. Los ricos emplean su fortuna en la amistad (Aristóteles, Ética nicomáquea, IV I, 2 = II20bi6; Retórica, I $5=$ 136ra28). La amistad como definición de las relaciones les aporta apariencia de igualdad $^{\text {so. }}$. Todos estos conceptos se han incluido ya en el tratamiento de las relaciones clientelares $^{\text {sI. }}$.

El préstamo entre amigos, sin interés, conocido como éranos, se cita en Antifonte, II 2, 9, como un sistema al que se acude «para no caer en la miseria ». El nombre indica que la práctica procede de las comidas en común con participación de todos. El simposio, como el gimnasio, eran espacios en los que tradicionalmente se forjaban vínculos o redes de amistad a los que se podía recurrir en años posteriores ${ }^{52}$. Los aspectos

47 P. Millett, Lending and Borrowing in Ancient Athens, Cambridge, 1991, 57-58.

48 Trad. de Juan Zaragoza (Madrid, Ed. Gredos, 1993).

49 Trad. de Emilio Lledó (Madrid, Ed. Gredos, 1986).

50 J. Oulhen, «La société athénienne», en P. Brulé, R. Descat (éds.), Le monde grec aux temps classiques, 2: Le IV'siècle, Nouvelle Clio, Paris, 2004, 332.

5 I Zelnick-Abramovitz, art. cit. (Did Patronage Exist), 67.

52 Humphreys, art. cit. (Public and Private), IOI-IO2, que se centra sobre todo en el reclutamiento de hetaîroi políticos en la esfera privada, sin caer en la cuenta de la vinculación que existe entre la dependencia política y la dependencia económica. 
rituales de la comensalidad se han adaptado a las necesidades de la época clásica, como modo de afirmar la solidaridad en estructuras sociales en las que se han disuelto las prácticas colectivas. En la tetralogía I (II I2) de Antifonte se mencionan los éranoi -junto a las liturgias, las contribuciones extraordinarias y el socorro económico a los amigoscomo prueba de las virtudes del defendido ${ }^{53}$. En Atenas un elevado número de préstamos se hacían sin requerir fianza o cargar intereses ${ }^{54}$.

Un ejemplo de ello es el discurso XLIX del corpus Demosthenicum, Contra Timoteo, atribuido a Apolodoro, quien lo libraría personalmente hacia $362^{55}$. Nos informa de uno de estos préstamos, concedido sin garantía y sin testigos (2), a Timoteo, estratego en la campaña corcirense de diez años antes; como la Asamblea no le había dotado de medios humanos y económicos suficientes, el hijo de Conón hipotecó sus propiedades a los trierarcos beocios aliados (II-I2) y solicitó préstamos personales al banquero Pasión (6-8); éste se hizo cargo además de las mil dracmas que Timoteo adeudaba a Filipo de Lamptras (I4-18), con el fin de apaciguar la creciente inquietud de unas tropas que aún no habían recibido la paga; Pasión ayudó a su amigo porque se encontraba en peligro, pero también porque esperaba que, una vez Timoteo se hubiera recuperado económicamente, podría obtener de él no sólo el pago de la deuda, sino cualquier otra cosa que necesitara (3). No fue así y Apolodoro, hijo de Pasión, muerto en 370/69, llevaría a Timoteo ante los tribunales para demandar la devolución de las 44 minas, 38 dracmas y 2 óbolos prestados (según Plutarco, Vida de Demóstenes, I5, ganó el proceso $)^{56}$. También tuvieron que recurrir a préstamos de sus philoi Aristófanes y Nicofemo, en Lisias XIX, Sobre los bienes de Aristófanes, 21-22, cuando su propio patrimonio familiar no fue suficiente para equipar diez trirremes que fueron enviadas, vacías por voto de la Asamblea, para apoyar la revuelta de Evágoras de Salamina contra el Gran Rey, sin duda a instancia de ellos mismos y de su prostátes Conón ${ }^{57}$. El hablante reconoce que su padre, al prestar las siete minas para pagar a los peltastas en una expedición que se prometía provechosa, esperaba cobrarse con creces el favor (23).

53 P.J. Rhodes, «Political Activity in Classical Athens», JHS 106, 1986, 137.

54 Véase Millett, op. cit. (Lending and Borrowing), I27-159..

55 Aunque prevalece la datación de Schäfer en 362, el discurso se ha situado, con diferentes argumentos, en distintos momentos entre comienzos de la década de 360 y comienzos de la siguiente; un reciente estado de la cuestión en Bianco, op. cit. (Lo stratego Timoteo), 98-99, que se inclina por el año 359.

56 Roberts, art. cit. (Aristocratic Democracy), 365 considera este caso un claro ejemplo de utilización de fondos privados para beneficio público. Cabe recordar que, según Lys. XIX, 39-40, Timoteo disponía a comienzos de los años 80 de un patrimonio valorado en veinte talentos.

57 Sobre estos hechos véase ahora C. Fornis, Grecia exhausta. Ensayo sobre la guerra de Corinto, Hypomnemata 175, Göttingen, 2008, 283-286. 
En general atender ese tipo de servicios se consideraba muestra de patriotismo cívico. Más tarde, Teofrasto, Caracteres, X II, describe la práctica de la comensalidad entre vecinos como un modo de redistribución y un instrumento para fortalecer los lazos entre los hombres. En efecto, la hetairía como grupo aristocrático solidario con proyección política en la ciudad, practicaba el éranos, entendido como la celebración de comidas en común, con aportes mutuos, como en Ciropedia, VII I, I2, como modo de suscripción para un amigo común; aquí Ciro trata de crear confianza, dentro de unas relaciones basadas en préstamos y otras prácticas de solidaridad dentro de los dominantes. A pesar de su carácter como bárbaro, Ciro el Grande como rey sirve de modelo para la recuperación de las tradiciones aristocráticas griegas en su pureza, aunque se hayan convertido en formas de beneficencia ${ }^{58}$. Los servidores, en esta situación, como en el caso de la esclavitud clásica, no lo son por anánke, sino por eúnoia y philía (Ciropedia, III I, 28). En cierto modo, el programa de Jenofonte es premonitorio de las características de la nueva sociedad del mundo helenístico, dominada por el poder personal de los reyes, apoyado y con el apoyo de las aristocracias, aunque en ocasiones surgieran problemas y diferencias entre ambas caras del poder. De este modo, los actos de protección de los necesitados se protagonizan, en consecuencia, por los primeros o las segundas. Los reyes ganan sus apoyos con políticas populistas de protección a los miserables, lo que en ocasiones provoca la reacción de las aristocracias que, ante algunos monarcas como Filipo V, o Perseo de Macedonia o Antíoco III de Siria, terminan buscando el apoyo romano como modo de garantizar su posición en calidad de clase dominante. Es característica del mundo helenístico la abundancia de declaraciones de evergetismo por parte de reyes o señores capaces de ofrecer determinados beneficios, sobre todo a los habitantes de las ciudades.

En Memorables, II 8, I, donde Sócrates se refiere a Eutero como un viejo hetaîron, éste ha perdido en la guerra sus pertenencias fuera del Ática y se ve forzado a trabajar; Sócrates le aconseja ponerse al servicio de alguien que tenga dinero y necesite ayuda ( 8 , 3), lo que él interpreta como una forma esclavitud, douleían $(8,4)^{59}$. La pobreza llega a ser, desde su punto de vista, similar a la esclavitud, pero Sócrates lo interpreta, a su vez, como una forma de intercambio, que sería equivalente a la práctica habitual entre opera et bona del mundo romano. Sócrates habla de vivir gracias a ello con menos peligro ( 8 , 6), en lo que se revela que la situación es el resultado de las condiciones de inestabilidad

58 D. Plácido, «La teoría de la realeza y las realidades históricas del siglo IV a.C.», en J.M. Candau, A. Ramírez de Verger, F. Gascó (eds.), La imagen de la realeza en la antigüedad, Madrid, 1988, 37-53.

59 Otros textos en que el trabajo dependiente aparece como una forma de esclavitud en K.J. Dover, Greek Popular Morality in the Time of Plato and Aristotle, Berkeley-Los Angeles, 1974, 40. 
social subsiguiente a la guerra. Son años duros, en los que la amistad, que no deja de ser una adquisición (ktêsis), se puede comprar más barato, como le dice Sócrates a Diodoro a propósito de Hermógenes, otro necesitado, aunque inteligente, que también se resiste a ser favorecido, por no poder corresponder (Io, 4). Sócrates hace ver a Diodoro lo provechoso de utilizar (chrésasthai) la amistad de Hermógenes, «un colaborador (byperétes) espontáneo, leal, constante, dispuesto a hacer no sólo lo que se le mande sino capaz de ser útil por propia iniciativa, de prevenir y de prever $\gg($ I, 3$)$. Es más ventajoso cuidar de este tipo de amigos que de los esclavos. Hermógenes cede sin esfuerzo, complacido de ser útil a quien considera, a su vez, su amigo (Io, 6). Se propone, pues, la recuperación de las relaciones clientelares también en el plano de la explotación del trabajo, a base del intercambio de utilidad contra la protección ${ }^{60}$. El Sócrates de Jenofonte busca el apoyo, para justificar la diferencia entre una y otra forma de dependencia, en la recuperación de las relaciones clientelares vinculadas a la hetairía. En II 9, 2, Sócrates se refiere a la posibilidad de tener a un hombre que haga de protector como el perro contra los lobos, como Arquedemo, que aparece como protector que ataca a los enemigos de Critón en

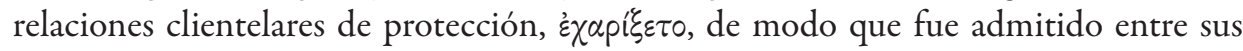
amigos $(9,5-8)$; se gana así sus favores a cambio de la protección en relaciones recíprocas

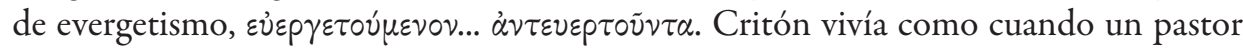
tiene un buen perro. Así entró Arquedemo en las amistades de Critón. Son tiempos que permiten tener buenos amigos por poco (II IO, 3-4), cuando alguien necesita recibir un favor y convertirse así en persona obligada ( $\left.\dot{\phi} \varepsilon \lambda \_u ́ \mu \varepsilon v \circ \varsigma\right)$, con lo que el evergetismo se define como forma de crear relaciones de clientela. Un colaborador leal equivale a tener muchos esclavos. Se trata de la situación crítica creada después de la guerra, en la que el libre necesitado puede encontrar cierta salida a sus problemas en la dependencia del dominante protector. Así se revela la doble cara de la teoría del perro guardián, como protector de dependientes y como protector del poderoso. El amigo es mucho más útil que los servidores. En tales relaciones, ambos tienen mucho que ganar, hay un interés compartido $(6)^{61}$. Ante la "crisis", entendida como alteración de las relaciones sociales propias del siglo $\mathrm{V}$, Jenofonte ve la solución en el restablecimiento de las relaciones

60 D. Plácido, «Resistencia, sumisión e interiorización de la dependencia. La dependencia como protección», SHHA, 25, 2007, 163-170. Contra, Konstan, op. cit. (Friendship), 79-82, para quien el Sócrates jenofóntico ejemplifica relaciones presididas por la generosidad y el sincero afecto hacia el amigo, no por la explotación.

61 Plácido, art. cit. (Resistencia), 167-168; cf. también Zelnick-Abramovitz, art. cit. (Did Patronage Exist), 69-70, que, en una interpretación claramente modernista, incide más en el carácter "comercial" de la relación entre Critón y Arquedemo: los ve como socios en una transacción o un negocio que dura tanto como el interés o el beneficio que extrae cada uno del mismo. 
entre evergetismo y cháris, como agradecimiento por la protección y las buenas acciones de los poderosos, capaces de alimentar por medio de la protección que permite al protegido la práctica de un trabajo "libre".

Los amigos se ayudan entre sí en caso de necesidad: en el seno de la hetería socrática, Platón, Critón, Critobulo y Apolodoro muestran su disposición a hacerse cargo de las treinta minas de multa impuesta a Sócrates (Platón, Apología, 38 b); Critón está dispuesto incluso a poner todos sus medios al servicio de la fuga del maestro, mientras Sinmias de Tebas, Cebes y otros muchos quieren contribuir con dinero a la empresa (Platón, Critón, 44 b-45 c) ${ }^{62}$. La obligación de ayudar es explícita en Jenofonte, Económico, II 5-9, que además relaciona todo lo demás que se espera de la prostasía de los ricos.

En ocasiones los amigos podían traicionar la confianza depositada en ellos -ápistos es sinónimo de áphilos en Platón, Leyes, 730 c-d)-, como en Dem. XXVII (Contra Áfobo I) 5, en donde el propio padre de Demóstenes pensó que dos sobrinos y un viejo amigo podrían velar por los intereses de sus hijos mientras eran menores de edad. En lugar de fortalecer los lazos de dependencia que les unían con la familia de Demóstenes, los tutores aprovecharon para privarles de sus propiedades ${ }^{63}$.

Las expresiones ideológicas del socratismo contaban ya con una cierta historia. Demócrito, DK68B255, plantea las ventajas de la concordia y la convivencia basadas en que los poderosos ayuden a los que no tienen, con lo que se hace posible llegar a ser hetaírous; desde época homérica, la hetairía era el ámbito de las relaciones clientelares, en la producción y en la política. Seguramente se debe a ellas la práctica de preparar los óstraka para lograr votos en contra de los enemigos políticos ${ }^{64}$. Arquitas, $\mathrm{DK}_{47} \mathrm{~B}_{3}$, por su parte, plantea la necesidad de que los eúporoi ayuden a los áporoi para evitar la stásis, mientras el autor del Anónimo de Jámblico (DK89, 7, 6) se pronuncia contra la tesaurización, a favor de la distribución, como arma frente a la tiranía ${ }^{65}$.

En las relaciones en las que se exhibe la ideología de la igualdad están escondidas normalmente relaciones verticales de patronato y clientela ${ }^{66}$. Por ello, cuando en el Contra Nicóstrato demosténico, el acusado, aprovechando que eran vecinos, hizo que un chico (paidárion) entrara en casa de Apolodoro, éste lo trató como esclavo (I6). En el modelo de evérgeta representado por Cimón, según Plutarco, Vida de Cimón,

62 F. Sartori, «Platone e le eterie», Historia 7.2, 1958, I57-171, esp. I6I-163, quien sin embargo despoja de toda entonación política a este tipo de relación entre los miembros del círculo socrático, reduciéndola a «un simple vínculo científico y afectivo».

63 Herman, op. cit. (Ritualised Friendship), $3 \mathrm{I}$.

64 W.R. Connor, The New Politicians of Fifth-Century Athens, Princeton, 1971, 26.

65 S. Mazzarino, Il pensiero storico classico, Roma-Bari, 1974, I, 318-322.

66 Gallant, op. cit. (Risk and Survival), 146. 
Io, se incluye la práctica de dejar a los vecinos acceso libre a las tierras, como hacía Apolodoro con Nicóstrato, práctica que aumentaba el prestigio de los aristócratas ${ }^{67}$. De hecho, en los Caracteres de Teofrasto, X 8-9, uno de los rasgos que definen la figura del «mezquino» (mikrologías) es el de impedir que haya quien recoja ni un higo, ni una aceituna o un dátil caído en el suelo, ni atraviese su tierra, mientras que en cambio revisa cada día los límites de su propiedad. Entre las perspectivas ideológicas del socratismo y de Aristóteles se desarrolla la idea de recuperar formas de relación en las que el misthós, como síntoma de esclavización, se sustituye por las relaciones clientelares basadas en el evergetismo y la cháris, sistema que puede asumirse en el plano de las aceptaciones voluntarias de la explotación, entre la beneficencia y la violencia simbólica ${ }^{68}$.

Demóstenes, XVIII, Sobre la corona, 268-269, hace constar sus acciones en favor de los necesitados, liberar de los enemigos y dotar a las hijas; piensa que el que lo recibe tiene que recordarlo todo el tiempo, sin necesidad de que se lo recuerden, pero el benefactor debe olvidar. En el discurso, Demóstenes hace una especie de examen de su vida en apoyo de la propuesta de Ctesifonte, seguidor suyo ${ }^{69}$, en 336 , de concederle le corona cívica por su méritos hacia la patria, a lo que se opuso Esquines, III, Contra Ctesifonte, en un proceso celebrado en 330. El contraataque de Demóstenes se basa en que Esquines, por familia y condiciones de vida servil, está destinado a venderse (I29-159), no ha hecho aportaciones económicas a la ciudad (3II), mientras que él presume de no omitir ninguna philotimía pública o privada y de ser útil (chrésimon) para la ciudad y para los amigos (257). Esquines había desempeñado trabajos serviles y adoptado el papel de un niño esclavo, no libre $(258)^{70}$.

Demóstenes, XIX, Sobre la embajada fraudulenta, I69, alude a sus actos de liberación de prisioneros, primero a través de un préstamo, que luego se transformó en un regalo (170). Demóstenes declara que ha tomado parte en la embajada para garantizar la liberación de los rehenes (17I) y no abandonar a los conciudadanos en su desgracia (172).

Demóstenes, LVII, Contra Eubulides, 25 hace alusión al caso de su padre, que es pariente y ayudó económicamente al padre del litigante.

67 D. Plácido, «El evergetismo de Cimón. El imperio de la aristocracia», en A.J. Domínguez, D. Plácido, F.J. Gómez Espelosín, F. Gascó, Historia del mundo clásico a través de sus textos. I. Grecia, Madrid, I999, 294-302.

68 D. Plácido, «Las relaciones clientelares en la evolución de la democracia ateniense», Circe, I2, 2008, 240-24I.

69 M.H. Hansen, The Athenian Democracy in the Age of Demosthenes, Oxford, 1991, 8.

70 S. Usher, Greek Oratory. Tradition and Originality, Oxford, 1999, 270-276. 
Sobre Estéfano, Demóstenes, LIX (Contra Neera) 72, datado poco antes de 340, dice que ayudó a Teógenes, noble pero pobre, al que le había tocado ser "rey", y luego lo hizo casar con la hija de Neera como si fuera su propia hija. Es uno de los discursos que se atribuyen a Apolodoro. El orador se pregunta (I3) cómo va nadie a tratar de obtener la ciudadanía del pueblo, lo que exige dinero y esfuerzos, cuando se puede obtener de un tipo como Estéfano con menos gasto. La ousía de Estéfano le proporcionaba dos servicios, sexual y doméstico (39). Es un sicofanta que promueve acusaciones públicas por dinero, denuncia y hace de testaferro en sentencias ajenas, aunque ni siquiera obtiene réditos apreciables (43). Estéfano dice al que se ha casado con su hija, hija de Neera, que por haberse aprovechado de ella tiene que hacer algún bien (70) y los árbitros deciden que pague la dote.

Midias, según Demóstenes, XXI, Contra Midias, 139, acusado de impiedad por el orador, que se había propuesto voluntario como corego, se halla entre aquellos ricos a quienes acuden a ayudar otros para obtener beneficios; ha intentado corromper al árbitro Estratón (83); era amigo de Eubulo (205-207), promovió la intervención en Eubea de 349 (IIO; 200). Por ello, Sealey ${ }^{71}$ piensa que Eubulo no era siempre partidario de la no intervención. Midias muestra su asélgeia (agresividad) y su hýbris con todos los ciudadanos, en lo que Demóstenes trata en cambio de identificarse con el conjunto de la ciudadanía (I $)^{72}$. El pueblo entero se ha sumado a pesar de su fortuna (2), lo que parece implicar que, incluso en la época democrática, el pueblo era más reacio a condenar a los ricos que a los pobres ${ }^{73}$, índice sin duda del peso de las relaciones clientelares, y el orador ha renunciado a cobrar lo que se le ofrecía por desistir (3). Es el argumento que parece haber utilizado Epícrates, según Lisias XXVII, Contra Epicrates, I, que habría amenazado con que su condena pondría en peligro la misthophorá. La acusación de Midias pretende que abandone la hýbris (4). Lo que ha hecho es sobornar a los jueces (5). También declara sus intenciones de limitar el poder de los ricos y las consecuencias de sus excesos $(8)^{74}$. En el contraste entre Estratón y Midias ve Ober ${ }^{75}$ el que corresponde al existente entre los "demóticos" y las minorías. El ideal democrático tiene que defenderse frente a la amenaza de los individuos poderosos que tratan de recuperar la cultura aristocrática ${ }^{76}$. Midias ha tratado de hacer fracasar la liturgia del orador, a base

7 I R. Sealey, «Athens after the Social War », JHS, 75, 1955, 77.

72 D.M. MacDowell, Demosthenes, Against Meidias (Oration 2I), edited with Introduction, Translation and Commentary, Oxford, 1990, 220.

73 MacDowell, op. cit., (Demosthenes), 221.

74 Ober, op. cit. (Athenian Revolution), 92-93.

75 Ober, op. cit. (Athenian Revolution), 100.

76 Ober, op. cit. (Athenian Revolution), ros. 
de corromper al arconte y a los coregos (17). Ha intentado comprar a los jurados del agón de los hombres (18). La gente teme entre otras cosas a su fortuna y a sus hetaîroi; ante ello se sitúan los que tratan de vengarse sin éxito o de buscar su apoyo, circunstancia que explica en 139; en esto consisten las claves del evergetismo y el clientelismo (20), en personas, además de las que cobran, que corren en su apoyo sin obtener ningún beneficio, sólo por su poder y su riqueza. En 26 queda de relieve la acción de poner obstáculos a los funcionarios en el ejercicio de su deber ${ }^{77}$. El tesmóteta se ha dejado persuadir por el dinero (39). Él en cambio no ha cobrado nada de Midias (40). Demóstenes (6I) ataca a Midias porque se comporta con violencia frente a quienes desempeñan las funciones a través de las liturgias. El problema es que un hombre por su poder personal pueda mostrarse más fuerte que las leyes, como Midias y los ricos que no tienen miedo de nada (66), cuestión contra la que va orientada el discurso. Midias intenta comprar los testimonios por medio del soborno (85). Consigue que sus enemigos sean «deshonrados» (91). Según los testigos, intenta corromper al árbitro (93).

Estratón ha quedado sin derechos de ciudadanía, ni de defenderse (95). La culpa de esta situación se encuentra en la riqueza de Midias, porque Estratón la despreció para respetar la ley al no aceptar el soborno; de haber aceptado tendría todos los derechos; las promesas de Midias se transforman en amenazas; el evergetismo es al mismo tiempo ejercicio del poder económico de manera opresiva $(96)^{78}$, por lo que Midias lo aprovecha para ofrecer sobornos. La riqueza es la causa de su býbris (98). No puede haber piedad con él al ver a una víctima suya como Estratón, un hombre pobre que ha caído en las peores desgracias por culpa de Midias (IоO). Midias actúa asimismo a través del pago de sicofantas, como Euctemón, para acusar a Demóstenes, pagado por Midias: misthosaménou ( $\mathrm{IO}_{3}$ ), en una relación que se identifica con el éranos, que coloca al que lo recibe en situación de dependencia ${ }^{79}$.

Midias promete dinero por acusar a Demóstenes de asesinato (IO4). Para Demóstenes, si no se ofrece resistencia a ese tipo poder, se llega a proskyneîn toùs hybrízontas, es decir, al poder personal (I06). Los testigos declaran que Midias les ha dado kérmata para que declaren contra Demóstenes (I07). Siempre cuando ejercía la liturgia (I08). Los ricos disfrutan de privilegios en las prácticas judiciales (II2), y eso que aceptar o dar algo para dañar al pueblo o alguno de los ciudadanos está castigado por la ley

77 M.H. Hansen, Apagoge, Endeixis and Ephegesis against Kakourgoi, Atimoi and Pheugontes. A Study in the Athenian Administration of Justice in the Fourth Century B.C., Odense, 1976, 74.

78 Demóstenes desea explotar la noción del rico que oprime al pobre, según MacDowell, op. cit. (Demosthenes), 319 .

79 MacDowell, op. cit., (Demosthenes), 323. 
citada en II3. Habla también de los peligros de que obligue a actuar por terror (I24) para librarse de las condenas (I25). La capacidad de violencia de Midias está relacionada con sus recursos, aphormé (I37). Su maldad y hýbris apoyadas en su potencia (exousía) y riqueza se convierten en una muralla contra la posibilidad de que le pase nada de repente (138). Lo protege un cuerpo de misthophóroi y una hetaireía de testigos, gentes siempre dispuestas a acudir junto a los ricos, asistirlos y serviles de testimonio. Las evergesias se identifican directamente con el misthós, que, al ser privado, crea relaciones clientelares, incluso sobre grupos más o menos organizados como heterías (139). Según el orador, esto es una amenaza para la comunidad, compuesta por personas inferiores en amigos (philois) y hacienda (I40). Su fuerza impide que lo acusen (I4I-I42). Para Demóstenes Alcibíades constituye un ejemplo del mal que puede causar el génos, la riqueza y la potencia (I43). A pesar de sus méritos, los antepasados de los miembros del jurado no soportaron su hýbris (I46). Midias intenta comprar a Demóstenes a través de quienes buscan convencerlo de que, en cualquier caso, como es rico utilizará sus trierarquías y liturgias como argumento (I5I). El orador piensa que las liturgias no pueden ser argumento para marcar una superioridad, como hace Midias, que presume de soportar los gastos ante el jurado $(\mathrm{I} 53)^{80}$.

Como trierarco, no se embarca en la nave, sino que envía al meteco egipcio Pánfilo (163). Con dotar una triere se descargaba de sus obligaciones militares (I65). Quiere aprovecharse de sus liturgias en el juicio (I69). Ni a los mayores benefactores se les puede permitir hybrizein (170). En los procesos, Midias recibe un trato favorable en comparación con los otros imputados por faltas parecidas (I8I y I82). Consigue poner a todos los oradores de su parte (190). Se dedicaba a injuriar a la Asamblea y al pueblo entero (194). Todos se exasperan con su fortaleza (thrasýteta), voz, aspecto, sus acompañantes, riqueza y hýbris (195). Se considera el único rico, el único que sabe hablar, los demás son impurezas (kathármata, desechos de las purificaciones), mendigos, y no hombres (198). Para Aristóteles, Retórica, II 2 (= 1378b, 26-27), la causa de la hýbris se encuentra en la búsqueda del placer, en el hecho de sentirse superior al otro, que es de lo que alardea Midias (47), de acuerdo con la ley citada por Demóstenes ${ }^{81}$. Con las acusaciones, Midias no se inmuta, insulta, apoya candidaturas, no se altera por los votos de censura (katacheirotonias) ni teme el proceso (200). Es difícil hacerle oposición: rico, fuerte, orgulloso, gritón, violento, desvergonzado (20I). Amenaza con suspender sus liturgias (la trierarquía) si el pueblo no quiere embarcarse (203), típico comportamiento

80 Ober, op. cit. (Mass and Elite), 209.

8I O. Murray, «The Greek Symposion in his History», en E. Gabba (ed.), Tria corda. Scritti in onore di A. Momigliano, Como, 1983, 252-272. 
de hýbris, que desprecia al pueblo (204), cuando las acciones tienen la humillación como objetivo $^{82}$. En una democracia no tendría que ser posible que la býbris quedara impune (207). Aconseja al jurado que no tenga en cuenta la riqueza ni el prestigio (dóxa) de Midias y sus amigos (210). Frente a los intereses particulares, Demóstenes se identifica con la pólis $(233)^{83}$. Para Demóstenes (2II), Midias merecería ser tan pobre como los más pobres, que identifica como mendigos, lo que se define como el modo de castigar su hýbris $^{84}$. De hecho, Aristóteles, Ética nicomáquea, VIII 4, I6 (= II63a29) considera que las liturgias no proporcionan honor, porque son ajenas a la philía ${ }^{85}$.

En la misma Ética nicomáquea, IX 9 (= $\left.{ }_{11} 69 b_{2}-8\right)$, argumenta sobre cuestiones referentes a la eudaimonía y piensa que los seres felices y autárquicos no dejan por ello de necesitar a los amigos, dado que éstos son como otro uno mismo, héteron autón, y el evergetismo es propio del hombre noble; Aristóteles convierte esta concepción de la amistad en la clave la de autorrealización humana (II70a-b) ${ }^{86}$. El propio Aristóteles, sin embargo, en II55a7-9, vincula estas relaciones con el evergetismo, como elemento fundamental de la koinonía (II59b25-60a30), en la correspondencia con la cháris. De este modo, los actos derivados de la philía se convierten en elementos de la convivencia cívica (Ética nicomáquea, IX $8=$ II 68a28-bi; Politica, II 3, I-2 $=$ I26IbI6-25) ${ }^{87}$, siempre que el beneficio se haga sin esperar devolución (Ética nicomáquea, IX $8=1162 b_{3} 6-37$ ). Sin embargo, añade (II67bı-18) que el que hace una buena restitución mira como su amigo a aquel para quien la ha hecho, y no al revés, y que dar y recibir es lo que vincula a los hombres en la vida (Epistola, 3$)^{88}$. En cambio el egoísmo destruye la amistad, con lo que se establece un paralelo similar al de Lisias, cuando se diferencia entre hacer el bien por generosidad o por sacar provecho (Magna Moralia, II I211a46; Diógenes Laercio, I 9I); Cleobulo de Lindo, uno de los siete sabios citados por Platón, Protágoras, 343a, decía que con el evergetismo se hacía mejores a los amigos, pero se hacía amigo el enemigo, pues hay que guardarse el reproche de los amigos y el ataque de los enemigos.

\footnotetext{
82 Ibid.

83 Ober, op. cit. (Athenian Revolution), 120.

84 Ober, op. cit. (Mass and Elite), 201.

85 Hands, op. cit. (Charities), 37-38.

86 E. Lledó, Memoria de la ética, Madrid, 1994, Iro-II3.

87 P.W. Ludwig, «Anger, Eros, and Other Political Passions in Ancient Greek Thought», en R.K. Balot (ed.), A Companion to Greek and Roman Political Thought, Chichester, 2009, 302.

88 Hands, op. cit. (Charities), 32-33.
} 
En la Ética eudemia, VII 3-4, Aristóteles marca la diferencia entre la amistad jerárquica y la igualitaria ${ }^{89}$. En ambos modos cambia la relación de reciprocidad, dado que todo don genera la obligación del contradón ${ }^{90}$, que sólo varía según las relaciones sociales entre ambos protagonistas. Aristóteles (Ética nicomáquea, V 3, 6= II3Ia2I-23) deja claro hasta qué punto influye en los cambios la diferencia entre las personas ${ }^{91}$. Por eso, según Aristóteles, el hombre justo necesita ser un hombre de medios (Ética nicomáquea, IV I, 24= II20b27; X 8, 4= $\left.1178 \mathrm{a} 24-\mathrm{b}_{2}\right)$. La clave se encuentra en la amistad (II55a7).

El corpus Lysiacum es una fuente clave para conocer el funcionamiento de las prácticas evergéticas y sus repercusiones a través de la cháris y los honores ciudadanos, por ejemplo en XXXI, Contra Filón, 30, donde pide que se recuerde por qué se honra a los que han sido buenos para con la ciudad y se priva de honores a los que han sido malos $^{92}$. De este modo, el evérgeta adquiere privilegios en la comunidad que pueden llegar a descargarlo de sus obligaciones cívicas.

En este comportamiento se encuadra la práctica de asistencia a los amigos, como aparece en Lisias XIX, Sobre los bienes de Aristófanes, 57-59. Aquí se relacionan las actuaciones de los ricos en las prácticas del evergetismo con las liturgias y las posibilidades de sacar provecho; en cambio el padre del orador se mantiene en la esfera de lo privado ( 18$)^{93}$. El autor ataca las prácticas de Aristófanes, que ha gastado mucho «para vosotros» cada año (Io), pero sabe que es muy difícil convencer al jurado por la penuria que sufre la ciudad; ésta habría que compensarla con las confiscaciones (II), lo que plantea el problema para los evérgetas, pues la confiscación no produce ningún beneficio; dice que ha gastado para alcanzar la timé (I8), dentro de los argumentos esgrimidos para obtener la cháris ${ }^{94}$ y satisfacer sus ambiciones políticas; de hecho, ha tenido problemas para desempeñar las liturgias (29); no siempre es fácil cumplir estas

89 M. Schofield, «Political Friendship and the Ideology of Reciprocity», en Cartledge, Millet, von Reden, op. cit. (Kosmos), 43-47.

90 J. Vélissaropoulos-Karakostas, «Merchants, Prostitutes and the 'New Poor'. Forms of Contract and Social Status», en P. Cartledge, E.E. Cohen, L. Foxhall (eds.), Money, Labour and Land. Approaches to the Economics of Ancient Greece, London-New York, 2002, 133.

9I D.J. Kyrtatas, «Domination and Exploitation», en ibid., I50.

92 F. Vannier, Finances publiques et richesses privées dans le discours athénien, Annales littéraires de l'Université de Besançon 362, Paris, 1988,106.

93 S. von Reden, «Demos' Phialê and the Rhetoric of Money in Fourth-Century Athens», en Cartledge, Cohen, Foxhall, op. cit. (Money), 56-57.

94 B.S. Strauss, Athens after the Peloponnesian War, London-Sidney, 1986, I3. 
obligaciones (30) ni siquiera para los que parecen ricos desde antiguo" ${ }^{95}$; insiste el orador en que las acciones de Aristófanes van más bien dirigidas a actuar como privado, idiai, en favor de sus conciudadanos, en las bodas de las hijas o en los funerales familiares; consideraba como deber del hombre noble (anèr agathós), ayudar a los amigos (phílous) (59); lo mismo que dice que había hecho su padre, «hacer gastos en favor de la ciudad y de los amigos» (56). Los argumentos se enmarcan en una defensa del ejercicio de los cargos como instrumento de redistribución, siempre que el único fin no sea sacar provecho frente al philótimos (57). Así, el orador piensa que ni siquiera el abogado debe mencionar las buenas acciones del benefactor, aunque ahora tiene necesidad de hacerlo (59). Pretende salvar el prestigio de su padre al referirse a la participación en las victorias hípicas (62-63).

En VII, Sobre el tocón sagrado, 3I-32, discurso que data de la década de 390, el acusado de arrancar un tocón de olivo sagrado, y por tanto cometer un delito de asébeia, afirma que ha cumplido con sus obligaciones litúrgicas con más celo y entusiasmo del que se le exigía y con más generosidad que cualquier otro ciudadano.

Otra forma de prestar servicio es costeando las armas de algunos compañeros de demo carentes de recursos, como se alega en XVI, En favor de Mantíteo, I4, y XXXI, Contra Filón, I5. Esta liberalidad de los más poderosos en el seno del demo generaba y fortalecía unos vínculos que, como ha dicho Rhodes, tenían «su lado siniestro», plasmado por ejemplo en el control de votos ${ }^{96}$.

El discurso XXVIII se dirige Contra Ergocles, un colaborador de Trasibulo de Estiria desde los tiempos de File, acusado de los cargos de $\delta \omega p o \delta o x i ́ a$ (corrupción),

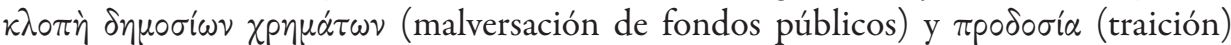
durante la campaña del Estirieo en el Helesponto en 390 y $389^{97}$. Por otro discurso lisíaco, el XXIX, Contra Filócrates, conocemos que Ergocles fue condenado a muerte y sus propiedades confiscadas al ser encontrado culpable de sustraer treinta talentos de los bienes públicos, suma que paradójicamente no apareció entre sus posesiones y de la que se responsabilizó a su amigo Filócrates. En lo que parece constituir un claro ejemplo de

95 Para las conexiones familiares y las propiedades que tenían en el Ática los personajes mencionados en la oratio XIX lisíaca, véase Davies, op. cit. (Athenian Propertied), $4 \mathrm{I} 2$ y C.A. Cox, Household Interests. Property, Marriage Strategies, and Family Dynamics in Ancient Athens, Princeton, 1998, 25-26.

96 Rhodes, art. cit. (Political Activity), I35-136.

97 La expedición de Trasibulo, de controvertida datación, se inserta en una difícil coyuntura para Atenas tras la muerte de Conón y el fracaso de las negociaciones de paz mantenidas en Sardes y Esparta; el Estirieo fracasará en su intento de restauración imperial basada en el expolio y la coerción sobre los aliados del Egeo y Asia Menor. Véase C. Fornis, «Trasibulo y el fracaso de la reconstrucción imperial ateniense en la guerra de Corinto», Klio 91, I, 2009, 7-28. 
relación vertical, el acusador señala que Ergocles ha beneficiado a su phílos, sacándole de las filas hoplíticas para convertirle primero en su administrador y más tarde en trierarco (3); puesto que de ser un hombre sin propiedades pasa a presentarse voluntario para la liturgia, asume que ésta no es un castigo, sino una recompensa que favorecía la ocultación de bienes, lo que le hace cómplice de las fechorías de Ergocles (4).

Debía de ser frecuente recibir ayudas de amigos y asociados en los tribunales, y no sólo en calidad de synégoroi que testifican a favor o en contra, razón por la cual el actor de Lisias XXVI, Sobre el examen de Evandro, I5, asegura no atacar a éste en su candidatura al arcontado epónimo en 382 para hacer un favor a Leodamante, amigo suyo, que había sido recusado para la misma magistratura por sus simpatías oligárquicas en un proceso anterior conducido por Trasibulo Coliteo; en el XV, Contra Alcibiades, una tritología o tercer discurso de acusación de dudosa atribución lisíaca, se denuncia la irregularidad de que los estrategos, instructores de un proceso por alistamiento indebido en la caballería, sin pasar por la correspondiente dokimasia, sean parciales y participen con sus declaraciones en la defensa del acusado, Alcibíades el Joven (I-6), en un juicio en el que claramente se ventilan disensiones políticas y se hace patente la larga sombra del celebérrimo padre del inculpado.

Arquedamo, abuelo de quien pronuncia el discurso VII, Sobre la herencia de Apolodoro, 8-9, de Iseo, supo corresponder a los favores recibidos de Apolodoro, primero contribuyendo a su rescate cuando fue hecho prisionero, luego dándole dinero cuando tuvo necesidad y, por último, adoptando a su hija y entregándola en matrimonio a un miembro del génos Eumólpida.

A pesar de la opinión que se presenta como dominante, las fuentes, sobre todo la oratoria, parecen demostrar que las relaciones creadas entre benefactores y beneficiados a lo largo del siglo IV responden al concepto generalmente admitido, para la Antigüedad como para otros períodos de la Historia, de relaciones clientelares. En este caso habría que admitir que la crisis de las relaciones de explotación dominantes a lo largo del siglo $\mathrm{V}$ abren las puertas a otras formas de dependencia que afectan a los sectores jurídicamente libres de la sociedad. Sin duda la esclavitud permanece, pero plantea una serie de nuevos problemas ante los que resulta más productivo acudir al deterioro de los estatutos cívicos para garantizar la continuidad de ciertos servicios relativos en general a actividades privadas. 